\section{Qualification for prevention of musculoskeletal diseases. Low back pain example}

\section{Kwalifikacja do profilaktyki schorzeń układu ruchu na przykładzie problematyki dolegliwości bólowych odcinka lędźwiowo-krzyżowego kręgosłupa}

\author{
Ernest Wiśniewski ${ }^{1 \mathrm{~A}, \mathrm{~B}, \mathrm{D}, \mathrm{F}}$, Aleksandra Zubrzycka ${ }^{1 \mathrm{~B}, \mathrm{D}}$, Zbigniew Wroński ${ }^{2 \mathrm{E}, \mathrm{F}}$, \\ Anna Hadamus ${ }^{2} \mathrm{C}, \mathrm{E}$ \\ ${ }^{1}$ Specialist Physiotherapy Practice Fabryka Zdrowia, Warsaw; \\ Specjalistyczna Praktyka Fizjoterapii Fabryka Zdrowia, Warszawa \\ ${ }^{2}$ Medical University of Warsaw, Rehabilitation Institute of Physiotherapy \\ Department, Second Faculty of Medicine; Warszawski Uniwersytet Medyczny, \\ Zakład Rehabilitacji Oddziału Fizjoterapii II Wydziału Lekarskiego
}

https://doi.org/10.5114/areh.2018.83390

\title{
Abstract
}

Introduction: In order to take a correct decision while qualifying for prevention programs, particularly in regard to persons with disability certificate, a detailed physiotherapeutic examination needs to be conducted. Currently practitioners are looking for methods allowing for quick assessment of patients' health before advising prevention or treatment. This paper examines the Functional Pain Index (FPI), a tool conceived by the authors, and compares the results with the results of the anamnesis and physical examination conducted by a physiotherapist.

Material and methods: Sample group consisted of 206 workers with disability certificate who have been experiencing low back pain (LBP). Each person went through physiotherapeutic examination, it was concluded by a decision to either qualify them for prevention program or advise LBP treatment. This result was compared with the FPI questionnaire and qualification based on the result produced by the questionnaire.

Results: The FPI based on three variables embedded in the questionnaire showed no statistically significant difference compared to a similar index based on the documentation produced by physiotherapeutic examination. Following the latter, 87 persons were qualified for prevention programs, with the FPI in this group ranging on average from 31.9 to 36.8 points, depending on the applied FPI variant. 119 persons were advised physiotherapeutic treatment or medical consultation, with the FPI in this group ranging from 51.8 to 57.5 points. It has been also shown that there is a statistically significant correlation between a decision of a physiotherapist to advise LBP prevention program and the FPI score in all its variants $(\mathrm{p}<0.001)$.

Conclusions: High consistency between the FPI based on the questionnaire and the index based on physiotherapeutic examination shows that the questionnaire is highly reliable. The FPI questionnaire can be a good alternative for qualifying patients for prevention programs, with questionnaire-based qualification for prevention program triggered in $0-40 \%$ range of the FPI.

Key words: $\quad$ occupational disease, work-related musculoskeletal disorders, low back pain, Functional Pain Index validity

email: zbigniewwronski@gmail.com

The research was financed from the authors' own resources

Badania sfinansowane ze środków własnych autorów 


\section{Streszczenie}

Wstęp: Prawidłowa kwalifikacja do programów profilaktycznych, szczególnie u osób ze stwierdzoną niepełnosprawnością, wymaga szczegółowego badania fizjoterapeutycznego. Obecnie poszukuje się metod szybkiej oceny stanu pacjenta w celu kwalifikacji do profilaktyki lub leczenia. Celem pracy była walidacja autorskiego Funkcjonalnego Wskaźnika Bólu (ang. Functional Pain Index - FPI) i porównanie jego wyników z wynikami badania podmiotowego i przedmiotowego przeprowadzonego przez fizjoterapeutę.

Materiał i metody: Grupę badaną stanowiło 206 pracowników z orzeczeniem o niepełnosprawności, u których utrzymywały się dolegliwości bólowe odcinka lędźwiowo -krzyżowego kręgosłupa. U każdej z osób przeprowadzono badanie fizjoterapeutyczne, kończące się podjęciem decyzji o kwalifikacji pacjenta do programów profilaktycznych lub skierowaniu na leczenie. Uzyskany wynik porównano ze wskaźnikami uzyskanymi w kwestionariuszu FPI i kwalifikacją na postawie jego wyniku.

Wyniki: Wskaźnik FPI wyliczany na podstawie trzech zmiennych z ankiety nie różnił się istotnie statystycznie od analogicznego współczynnika wyliczonego na podstawie dokumentacji z badania fizjoterapeutycznego. Na podstawie badania fizjoterapeutycznego do programów profilaktycznych zostało zakwalifikowanych 87 osób, a wartości wskaźnika FPI wynosiły w tej grupie średnio 31,9-36,8 pkt. w zależności od zastosowanej wersji wskaźnika. 119 osób zostało skierowanych na fizjoterapię lub konsultację lekarską i w grupie tej wartości wskaźnika kształtowały się od 51,8 do 57,5 pkt. Wykazano również istotną statystycznie zależność między decyzją fizjoterapeuty o skierowaniu na profilaktykę a wartością wskaźnika FPI dla wszystkich jego wersji $(\mathrm{p}<0,001)$.

Wnioski: Duża zgodność pomiędzy wskaźnikiem FPI wyliczonym z ankiety oraz z badania fizjoterapeutycznego świadczy o wysokiej wiarygodności kwestionariusza. Kwestionariusz FPI może być dobrą alternatywą przy kwalifikacji pacjentów do programów profilaktycznych, a zakres do kwalifikacji na podstawie kwestionariusza stanowi 0-40\% wskaźnika FPI.

Słowa kluczowe:

choroba zawodowa, zaburzenia mięśniowo-szkieletowe, ból dolnej części pleców, funkcjonalny wskaźnik bólu

\section{Introduction}

Work-Related Musculoskeletal Disorders (WRMSDs) are the main cause of disability, absenteeism in the workplace, and reduced productivity in the EU [1]. Especially Low Back Pain (LBP) [2] is viewed as an increasingly severe epidemic of our times $[3,4]$, despite the availability of various methods of treatment.

There is a number of standardized questionnaires monitoring the progress of LBP treatment, and they are used to assess the functional condition of patients in various aspects of their professional and social life. They include Health Assessment Questionnaire - Disability Index (HAQ-DI), Oswestry Low Back Pain Disability Questionnaire (ODI), The Work Productivity and Activity Impairment Questionnaire (WPAI), and many others [5,6,7]. These questionnaires usually focus on acute low back pain, which largely prevents patients from participating in family, social, and professional life.
However, they are rather lengthy and ask many complex questions, and deriving results from the answers is complicated and time-consuming. Very often the pain is persisting, has varying intensity, but never eases off completely. Nevertheless, those suffering from it continue showing up at work. In the literature, this behavior is called presenteeism and describes inefficient presence at work [8]. It has been established that prolonged presenteeism exacerbates health problems, reduces workplace efficiency, and increases absenteeism in the future [9]. It also generates some indirect costs, that is, lost profit caused by reduced productivity - in Western countries, indirect costs account for more than half of costs related to occurrence and treatment of diseases [10]. Costs of presenteeism paid by businesses are 2-3 times larger than direct costs of health care [11].

This points to a need for tools that would assess chronic pain, and this need was addressed by the project undertaken by our team, which included, 
among others, research presented in this paper. The goal was to validate the Functional Pain Index (FPI), a tool conceived by the authors, and compare the results with the results produced by the interview and physiotherapeutic examination conducted by a physiotherapist. The authors also attempted to determine a point range of the FPI questionnaire which would trigger qualification for a prevention program. Picture 1. shows the methodology used in calculating the FPI.

1. Please use the below scale ranging from 0 to 10 (where 0 means no pain at all, and 10 means the worst imaginable pain) to describe how intense your low back pain is . When describing your pain please think about its average intensity experienced in the last 7 days.

\begin{tabular}{|l|l|l|l|l|l|l|l|l|l|l|l|}
\hline Intensity [NRS] & 0 & $\mathbf{1}$ & $\mathbf{2}$ & $\mathbf{3}$ & $\mathbf{4}$ & $\mathbf{5}$ & $\mathbf{6}$ & $\mathbf{7}$ & $\mathbf{8}$ & $\mathbf{9}$ & $\mathbf{1 0}$ \\
\hline
\end{tabular}

2. How often do you feel pain?

\begin{tabular}{|l|c|c|c|c|c|}
\hline \multicolumn{1}{|c|}{ Frequency } & \multicolumn{5}{c|}{ FPI variant } \\
\cline { 2 - 6 } & I & II & III & IV & V \\
\hline Constantly, practically all the time, only with varying intensity & 4 & 8 & 10 & 10 & 10 \\
\hline $\begin{array}{l}\text { Daily, but there are moments when I don't feel any pain or } \\
\text { forget about it }\end{array}$ & 3 & 6 & 7 & 7.5 & 8 \\
\hline Often, several times a week & 2 & 4 & 5 & 5 & 6 \\
\hline Sporadically, 3-4 times a month & 1 & 2 & 2 & 2.5 & 3 \\
\hline Hardly ever, to the extent it's not a concern for me & 0 & 0 & 0 & 0 & 0 \\
\hline
\end{tabular}

3. How much low back pain impacts your private and professional life?

\begin{tabular}{|l|c|c|c|c|c|c|}
\hline \multicolumn{2}{|c|}{ Coping with pain } & \multicolumn{7}{c|}{ FPI variant } \\
\cline { 2 - 7 } & I & II & III & IV & V \\
\hline The pain is so weak and infrequent that it's not an issue & 0 & 0 & 0 & 0 & 0 \\
\hline $\begin{array}{l}\text { I'm not able to cope with pain in my private and professional } \\
\text { life without taking drugs }\end{array}$ & 1 & 2 & 2 & 2.5 & 3 \\
\hline $\begin{array}{l}\text { Taking drugs allows me to live my private and professional life } \\
\text { normally }\end{array}$ & 2 & 4 & 5 & 5 & 6 \\
\hline $\begin{array}{l}\text { The methods I use (pharmacological and others) no longer } \\
\text { reduce pain symptoms so that I can live my private and } \\
\text { professional life normally }\end{array}$ & 3 & 6 & 7 & 7.5 & 8 \\
\hline \begin{tabular}{l} 
The pain completely dominates my private and professional life \\
\hline
\end{tabular} & 4 & 8 & 10 & 10 & 10 \\
\hline
\end{tabular}

Ryc. 1. Methodology used in calculating the FPI

\section{Material and methods}

For the person to be eligible for participation in the research they had to have a disability certificate. The sample group consisted of 206 workers with disability certificate ( $72 \%$ women vs. $28 \%$ men), employed in 16 sheltered workshops in Poland. The average age was 50.2 y.o. (median: 53 y.o.) a detailed breakdown into specific age groups is shown in table 1 . Workers who showed symptoms requiring further medical tests were excluded from the research. 
Tab. 1. Quantitative breakdown into age groups

\begin{tabular}{cccccc}
\hline & $\leq 35$ & $35-44$ & $45-54$ & $55-64$ & $\geq 65$ \\
\hline Number (N) & 19 & 34 & 63 & 83 & 7 \\
\hline Share (\%) & $9.3 \%$ & $16.5 \%$ & $30.6 \%$ & $40.2 \%$ & $3.4 \%$ \\
\hline
\end{tabular}

The largest group, 119 persons (57.8\%), performed their work while sitting at the computer. 41 persons $(19.9 \%)$ performed physical work while sitting, 46 persons $(22.3 \%)$ performed other physical work.
Among surveyed workers of sheltered workshops, 193 persons (93.7\%) reported pain lasting over 3 months, and from among these persons as much as 176 persons $(85.4 \%)$ have been experiencing pain for 12 months or longer (table 2).

Tab. 2. Pain characteristics in the sample group

\begin{tabular}{|c|c|c|c|}
\hline Pain Duration & Share $(\%)$ & Pain Frequency & Share $(\%)$ \\
\hline$<12$ weeks & $6.3 \%$ & Once a month or less frequently & $13.1 \%$ \\
\hline 12 weeks -1 year & $8.3 \%$ & Sporadically, 2-4 times a month & $23.8 \%$ \\
\hline $1-3$ years & $17.0 \%$ & Often, several times a month & $27.2 \%$ \\
\hline $3-10$ years & $37.9 \%$ & Daily, but there are moments I don't feel any pain & $23.8 \%$ \\
\hline years & $18.0 \%$ & \multirow{2}{*}{$\begin{array}{c}\text { Constantly, practically all the time, only with va- } \\
\text { rying intensity }\end{array}$} & \multirow{2}{*}{$12.1 \%$} \\
\hline$>20$ years & $12.6 \%$ & & \\
\hline
\end{tabular}

The FPI used in the research was developed basing on questions conceived by the authors and was applied to assess the initial limitations in daily and professional life depending on the intensity of experienced pain. The questionnaire prepared by the authors had 15 questions inquiring about pain symptoms, its location, duration, and characteristics. The answers were used to assess whether those surveyed meet the criteria that determine whether or not a prevention program should be advised. Only 3 questions were used to calculate the FPI, and each was attributed point and percentage score. Since the FPI is a newly designed tool, point scores were estimated for various variants. After preliminary analysis 5 variants for calculation of the FPI were selected and examined throughout the project to ensure the best possible presentation of results. Choosing a smaller number of variants would oversimplify the matter, while more variants would compromise transparency. Questions used to calculate the FPI and calculation variants for the FPI are shown in picture 1. Maximal score in the questionnaire, depending on the variant, was: I - 18 points, II -26 points, III, IV and $\mathrm{V}-30$ points each. Pain classification as per the FPI is shown in table 3.
Tab. 3. Percentage share for each FPI variant

\begin{tabular}{|c|c|c|c|c|c|c|}
\hline FPI & $\%$ & I & II & III & IV & $\mathbf{V}$ \\
\hline $\begin{array}{l}0 \%-20 \% \\
\text { - minimal }\end{array}$ & $20 \%$ & $0-4$ & $0-5$ & $0-6$ & $0-7$ & $0-8$ \\
\hline $\begin{array}{l}21 \%-40 \% \\
\text { - moderate }\end{array}$ & $40 \%$ & $5-7$ & $6-10$ & $7-12$ & $7-13$ & $7-14$ \\
\hline $\begin{array}{l}41 \%-60 \% \\
\text { - persistent }\end{array}$ & $60 \%$ & $8-10$ & $11-15$ & $13-18$ & $13-19$ & $13-20$ \\
\hline $\begin{array}{l}61 \%-80 \% \\
\text { - paralyzing }\end{array}$ & $80 \%$ & $11-14$ & $16-20$ & $19-24$ & $19-25$ & $19-26$ \\
\hline $\begin{array}{l}81 \%-100 \% \\
\text { - extreme }\end{array}$ & $100 \%$ & $15-18$ & $21-26$ & $25-30$ & $25-31$ & $25-32$ \\
\hline
\end{tabular}

The research was conducted between November 2015 and March 2016, and was completed in 2 stages. In the 1st stage those surveyed were asked to access an e-learning platform to fill the questionnaire on their own - the collected data were used to calculate the FPI. The questions were ciphered to ensure that their true purpose was obscure to those surveyed. In the 2nd stage an interview and physiotherapeutic examination were conducted in a separate room. Where no dangerous symptoms were observed [12], a physiotherapist qualified those surveyed for a back pain prevention program or suggested physiotherapeutic treatment. Where the cause of pain was not clear, a medical consultation for further inquiry into the cause was suggested. A physiotherapist conducting the examination was not familiar with how questionnaires were filled in the 1st stage of the research, and their assessment was independent and final. 
A statistical analysis was conducted with SAS software, using the Wilcoxon test, the $\mathrm{Chi}^{2}$ test, and the Spearman correlation coefficient, with statistical significance threshold set at $\mathrm{p}=0.005$.

\section{Results}

The FPI calculated basing on three variables embedded in the questionnaire showed no statistically significant difference when compared to a similar index determined basing on documentation produced by physiotherapeutic examination.

Basing on physiotherapeutic examination, prevention programs were advised to 87 persons, with the FPI for this group ranging in average from 31.9 to 36.8 points, depending on the index variant applied. 119 persons were advised physiotherapy or medical consultation, with the FPI for this group ranging on average from 51.8 to 57.5 points, depending on the index variant applied. A comparison of groups shows that they differ in a statistically significant manner $(p<0.0001)$ in all
FPI variants. Detailed results were presented in table 4.

Tab. 4. Comparison of persons qualified and not qualified for a prevention program in all FPI variants

\begin{tabular}{|l|c|c|c|}
\hline $\begin{array}{l}\text { Physiotherapist } \\
\text { Decision }\end{array}$ & $\mathbf{N}$ & FPI version & Average \pm SD \\
\hline \multirow{4}{*}{$\begin{array}{l}\text { Physiotherapy } \\
\text { or medical } \\
\text { consultation }\end{array}$} & \multirow{3}{*}{119} & FPI I & $55.1 \pm 16.2$ \\
\cline { 3 - 4 } & & FPI II & $53.8 \pm 16.5$ \\
\cline { 3 - 4 } & & FPI III & $51.8 \pm 17.0$ \\
\cline { 3 - 4 } & & FPI IV & $53.4 \pm 16.7$ \\
\hline \multirow{4}{*}{ Prevention } & FPI V & $57.5 \pm 16.6$ \\
\hline \multirow{3}{*}{87} & FPI I & $34.5 \pm 17.2$ \\
\hline & & FPI II & $33.8 \pm 17.5$ \\
\hline & & FPI III & $31.9 \pm 17.6$ \\
\cline { 3 - 4 } & & FPI IV & $33.6 \pm 17.7$ \\
\cline { 3 - 4 } & & FPI V & $36.8 \pm 18.9$ \\
\hline
\end{tabular}

Results show that at lower FPI scores (up to $20 \%$ ) recorded in specific FPI variants, back pain prevention was suggested for $83.33 \%-88.89 \%$ of those surveyed in the sample group (picture 2).

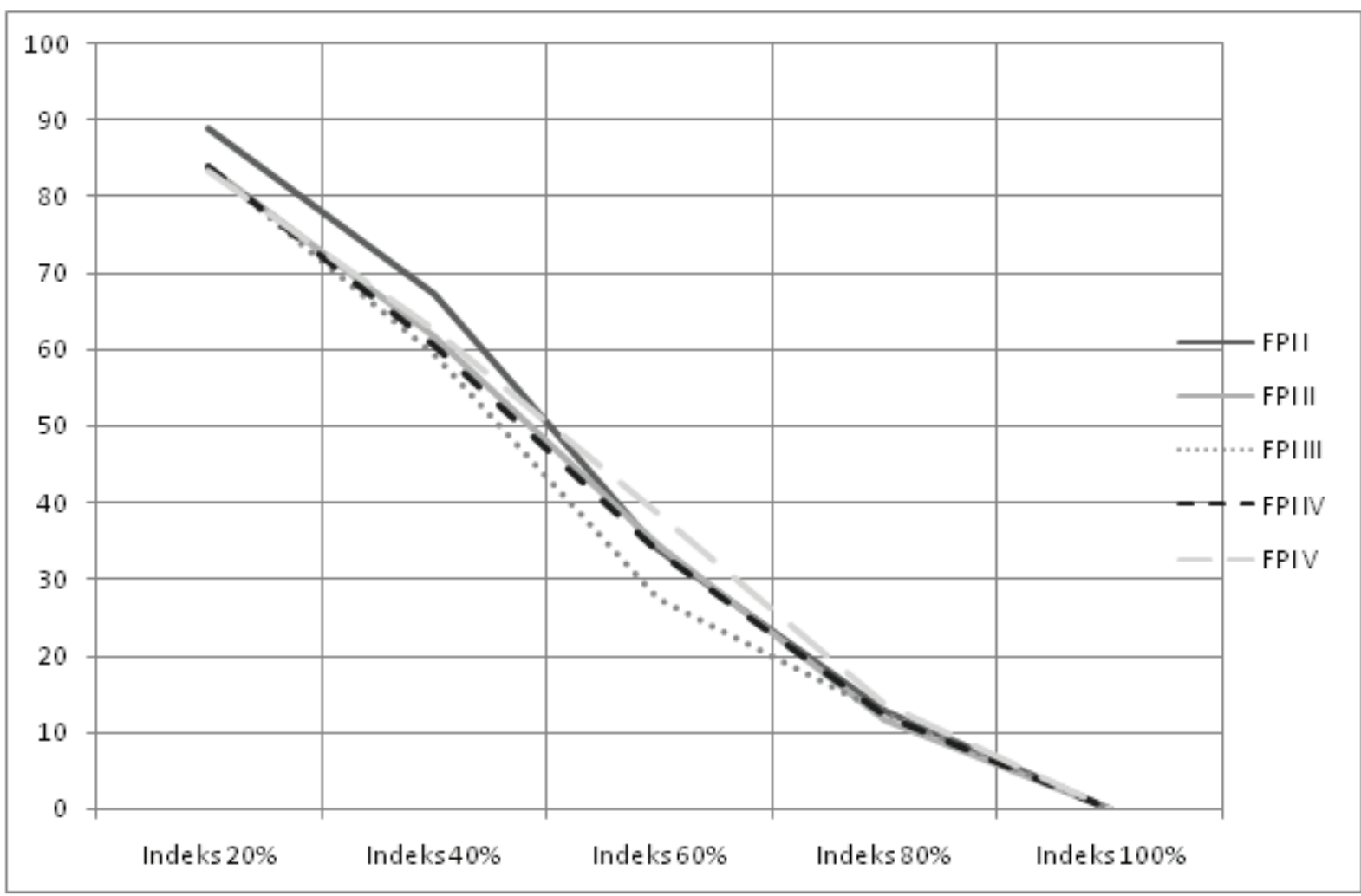

Ryc. 2. Persons qualified for prevention [\%] depending on the FPI variant 
For the FPI at $40 \%, 60 \%$ and $80 \%$, a prevention program was advised to, respectively, 59.32\%$67.21 \%, \quad 27.5 \%-38.46 \%$ and $11.63 \%-13.73 \%$ of those surveyed. Where the highest FPI score $(100 \%)$ was recorded, all persons were advised medical consultation and treatment. There was also a negative correlation between the FPI score and the number of persons qualified for back pain prevention $(p<0.005)$. This correlation is presented in picture 2 and includes all FPI variants. It has been also established that there is a statistically significant correlation between a decision to advise back pain prevention and the FPI score in all its variants $(\mathrm{p}<0.001)$.

\section{Discussion}

While determining whether a person is eligible for a prevention program one needs to decide whether such prevention is advisable as well as assess the functional condition of a patient in order to ascertain whether they should seek medical consultation and treatment [13]. When encountering symptoms that may have their source in the spine one may consider consulting with a neurosurgeon [14]. Currently Poland has no standardized and nationwide back pain prevention programs, and Supreme Audit Office has never produced any reports shedding light on prevention of musculoskeletal problems. Systemic prevention is practically non-existent in the guaranteed healthcare services system as it exists in Poland today.

Back pain prevention comes into question when pain has been experienced recently or has been recurring, radiating to a lower extremity, or causing absenteeism [14]. In order to assess risk factors which, when established, should result in specialist treatment, one should conduct a detailed examination of pain intensity and complete a check for possible „red flags.” According to the latest research, LBP is associated with 41 risk factors, 51 concomitants and 39 parallel diseases, some of which are difficult to tell apart $[15,16]$. In the process of qualifying for back pain prevention one may use standardized questionnaires typically used to assess progress in treatment $[5,6,7]$. They provide, however, too much data difficult to interpret using only algorithms, and so usually one resorts to various forms of a questionnaire which, after initial analysis, allows to single out patients suffering from recurring back pain who could benefit from prevention programs [14]. At the same time, the questionnaire is designed in such a way as to separate patients who potentially need a detailed physiotherapeutic examination and, possibly, treatment.

The questionnaire and the FPI developed by our team allow to assess how advanced the pain is. The results described above show a high consistency between answers given in the questionnaire and answers given to a physiotherapist during the interview, proving the questionnaire's reliability. Regardless of the questionnaire variant, the general correlation does not change between the FPI score and a decision whether back pain prevention should be advised or not. One may conclude that the choice of questions from which the FPI is derived was correct and consistent with criteria applied by a physiotherapist exercising their individual judgment.

Considering the results in relation to various FPI variants (1-5), one may also note that variants 2 and 4 are quite closely matched. Furthermore, compared to other variants, variant 3 is characterised by a low-point score in the entire middle range (20-80\%). Variant 1 produces overstate results in $0-40 \%$ range, while variant 5 produces higher results in $40-80 \%$ range. Considering in addition that the results are linear, we conclude that the most reliable FPI variants are variants 2 and 4 .

It has been observed that a critical point while qualifying for back pain prevention or physiotherapy/ consultation occurs in the FPI score ranging from $40 \%$ to $60 \%$. One may therefore tentatively assume that all persons with results within $0-40 \%$ range of the FPI (minimal or moderate pain) can be safely qualified for prevention programs. For the FPI ranging from $40 \%$ to $60 \%$ (persisting pain) one would suggest an additional assessment with follow-up "red flag" questions asked in the e-qualification system [12]. Finally, persons with the FPI above $60 \%$ (persisting or extreme pain) should be examined by a physiotherapist before being advised back pain prevention or treatment. It should be noted, however, that a simulation exercise should be conducted to verify these observations.

The FPI enables assessment of the initial condition of patients complaining about persisting back pain. It can be probably also applied to monitor progress in back pain treatment, and may be useful in system-wide qualification as a complementary tool for software-enabled qualification for back 
pain prevention, with one of its core advantages being simplicity (3 questions) - as opposed to other questionnaires available today which are characterized by high complexity.

\section{Conclusions}

1. High consistency between the FPI based on the questionnaire and physiotherapeutic examination proves that the questionnaire is highly reliable.
2. Correlation between a physiotherapist decision to qualify for back pain prevention and the result produced by the FPI questionnaire shows that it can serve as a good alternative for qualifying patients for prevention programs, with questionnaire-based qualification for a prevention program triggered in $0-40 \%$ range of the FPI.

3. As a new assessment tool, the FPI questionnaire needs to be refined by determining its most optimal variant, followed by a relevant simulation exercise based solely on this choice.

\section{Reference}

1. Bevan S. Economic impact of musculoskeletal disorders (MSDs) on work in Europe. Best Pract Res Clin Rheumatol. 2015 Jun;29(3):356-73.

2. Van Eerd D, Munhall C, Irvin E, Rempel D, Brewer S, van der Beek A et al. Effectiveness of workplace interventions in the prevention of upper extremity musculoskeletal disorders and symptoms: an update of the evidence. Occup Environ Med. 2016 Jan; 73(1):62-70.

3. Oliveira CB, MaherCG, Pinto RZ, Traeger AC, Lin CWC, Chenot JF et al. Clinical practice guidelines for the management of non-specific low back pain in primary care: an updated overview. Eur Spine J. 2018 Nov;27(11): 2791-803.

4. Bugajska J i wsp. Nabyte zespoły dysfunkcji układu mięśniowo-szkieletowego u pracowników w świetle badań epidemiologicznych. Med Pr. 2011;62(2):153-160.

5. Grönblad M, Järvinen E, Hurri H, Hupli M, Karaharju EO. Relationship of the Pain Disability Index (PDI) and the Oswestry Disability Questionnaire (ODQ) with three dynamic physical tests in a group of patients with chronic low-back and leg pain. Clin J Pain. 1994 Sep;10(3):197-203.

6. Majid K, Truumees E. Epidemiology and Natural History of Low Back Pain. Semin Spine Surg. 2008;20:87-92.

7. Manek NJ, MacGregor AJ. Epidemiology of the back disorders: prevalence, risk factors and prognosis, Curr Opin Rheumatol. 2005 Mar; 17(2):134-40.

8. Malińska M. Prezenteizm - zjawisko nieefektywnej obecności w pracy [Presenteeism]. Med Pr. 2013;63(3):439-47.

9. Johns G. Presenteeism in the workplace: A review and research agenda. J Organ Behav. 2010 Jul;31:519-42.

10. Jakubczyk M, Wrona W, Macioch T, Golicki D, Niewada M, Hermankowski T. Koszty pośrednie w ocenie technologii medycznych. Pol. Med. J. 2010;28(163):42-5.

11. Hemp P. Presenteeism: At work - but out of it. Harv Bus Rev. 2004 Oct;82:49-58.

12. Leerar P, Boissonnault W, Domholdt E, Roddey T. Documentation of Red Flags by Physical Therapists for Patients with Low Back Pain. J Man Manip Ther. 2007;15(1):42-9.

13. Burton K, Balagué F, Cardon G, Eriksen HR, Henrotin Y, Lahad A, et al. European guidelines for prevention in low back pain. Eur Spine J. 2006 Mar;15(Suppl 2):s136-68.

14. Rantonen J, Karppinen J, Vehtari A,Luoto S, Viikari-Juntura E, Hupli M et al. Effectiveness of three interventions for secondary prevention of low back pain in the occupational health setting - a randomised controlled trial with a natural course control. BMC Public Health. 2018 May 8;18(1):598.

15. Green BN, Johnson CD, Haldeman S, Griffith E, Clay MB, Kane EJ et al. A scoping review of biopsychosocial risk factors and co-morbidities for common spinal disorders. PLoS One. 2018 Jun 1;13(6):e0197987.

16. Green BN, Johnson CD, Haldeman S, Kane EJ, Clay MB, Griffith EA et al. The Global Spine Care Initiative: public health and prevention interventions for common spine disorders in low- and middle-income communities. Eur Spine J. 2018 Sep;27(Suppl 6):838-50. 